Plant Tissue Cult. \& Biotech. 23(2): 241-249, 2013 (December)

$\underline{\text { PTC\&B }}$

\title{
In vitro Embryo Morphogenesis and Micropropagation of Dendrobium aggregatum Roxb.
}

\section{Mohammad Musharof Hossain}

Plant Tissue Culture and Biotechnology Laboratory, Department of Botany, University of Chittagong, Chittagong-4331, Bangladesh

Key words: Embryo morphogenesis, Seed germination, Organogenesis,

Dendrobium aggregatum

\begin{abstract}
In vitro embryo morphogenesis and micropropagation of Dendrobium aggregatum Roxb. were described. The gradual developmental stages of embryos to seedlings were traced out. Within two weeks of culture the cells of undifferented embryos underwent repeated aniclinal and periclinal division producing a compact, green parenchymatous cell mass called spherule that emerged out by rupturing the testa. The spherules subsequently differentiated into greenish protocorms were considered as typical seed germination. Germination occurred on both (MS and Phytamax (PM) medium but MS medium proved to be more efficient. The primary protocorms underwent profuse proliferation through production of secondary $\left(2^{\circ}\right)$ protocorms when transferred to different plant growth regulators (PGRs) supplemented MS; the medium fortified with $2.0 \mathrm{mg} / \mathrm{l} \mathrm{BAP}$ and $1.0 \mathrm{mg} / \mathrm{l}$ NAA proved to be most effective for induction of $2^{\circ}$ protocorms and seedling development. Multiple shoot buds (MSBs) were induced in pseudobulb segments of the in vitro grown seedlings when cultured on different PGRs supplemented media; and the maximum number of MSBs were obtained MS + $2.0 \mathrm{mg} / \mathrm{l} \mathrm{BAP}+0.5 \mathrm{mg} / \mathrm{l}$ picloram. The MSBs underwent elongation and then they rooted when they were transferred to half strength of MS $+0.5 \mathrm{mg} / \mathrm{l} \mathrm{IAA}$. The well rooted plantlets were finally transferred to outside natural environment with $80 \%$ survival.
\end{abstract}

\section{Introduction}

Dendrobium aggregatum Roxb. (Syn. D. lindleyi Steud.) is an evergreen epiphytic orchid characterized by beautiful showy spikes of orange-yellow flowers, sporadically found in the Teknaf forest of Cox's Bazar district of Bangladesh (Ahmed 1991, Huda et al. 1999). The species has a great horticultural importance for its flowers of exquisite beauty as well as potted plant for decorating the Lobby. The natural orchid gene pool is depleting at an alarming rate due to 
overexploitation for medicinal and ornamental purposes, onslaught habitat destruction by urbanization and shifting cultivation, loss of pollinators, destructive diseases, climate changes and unauthorized trade (Hossain 2009). Considering the present status of orchids, the family Orchidaceae as a whole was included in the CITES (Convention on International Trade in Endangered Species) (Shefferson et al. 2005). In the context of commercial exploitation, and to meet up future demand and conservation it is important to develop rapid, reliable and reproducible propagation techniques of this economically important orchid species. Since the discovery of in vitro seed germination of orchids by Knudson (1922) and the micropropagation technique by Morel (1964) the technique is routinely used for mass multiplication of economically important orchids. In fact, the discovery of tissue culture techniques added a new dimension to the production of quality plants in large quantities and propagation of exquisite and rare orchids (Stenberg and Kane 1998, Nagashima 1999, Seeni and Latha 2000, Hossain 2008, Sinha et al. 2009, Hossain et al. 2009, 2010, 2012). Although tissue culture techniques have been adapted in a number of orchid species the information for D. aggregatum is rare. Recently, Vijayakumar et al. (2012) reported only germination of immature seeds of D. aggregatum. Considering the importance, the present investigation was undertaken with a view to developing an efficient and reproducible protocol for in vitro germination and micropropagation of $D$. aggregatum. The protocol reported here suggests that same has a potential of providing mass supply of planting material to meet the demands of orchid growers as well as for conservation. A special attention was also paid to investigate the mode of morphogenesis of embryo during formation of protocorm and seedling development.

\section{Materials and Methods}

Plants of Dendrobium aggregatum Roxb. were collected from their natural habitat of Teknaf forest of Cox's Bazar district of Bangladesh and grown in the Orchidarium of the Botanical Garden of Chittagong University. Several flowers were hand pollinated on the second and third day of anthesis. The pollinated flowers were bagged with a thin transparent polythene bag for one week and then removed Several capsules were collected after three - four months of pollination and the seeds were used for in vitro germination. MS and PM (Phytamax; Sigma Chemical Co. USA) media were used for in vitro studies. $\mathrm{pH}$ of the media was adjusted to 5.4 for PM and 5.8 for MS prior to autoclaving at $121^{\circ} \mathrm{C}$ for $20 \mathrm{~min}$. at $15 \mathrm{psi}$.

The capsules were cleaned with $20 \%$ Teepol, a commercial detergent (Qualigens Fine Chemicals, Mumbai, India) and washed thoroughly under 
running tap water. These were then surface sterilized by submerging the material in $0.2 \%(\mathrm{w} / \mathrm{v}) \mathrm{HgCl}_{2}$ solution for $10 \mathrm{~min}$ with occasional agitation followed by a dip in $70 \%$ ethanol for $1 \mathrm{~min}$ and rinsed two - three times with sterile distilled water and then cut longitudinally with a sterile surgical blade keeping the material on a piece of sterile aluminum slab inside a laminar airflow cabinet. The powdery seeds were taken out and were inoculated on the surface of agar gelled nutrient medium in culture vessels (test tubes $2.5 \times 15 \mathrm{~cm}$ and conical flasks $250 \mathrm{cc}$ ) for germination. The culture vessels with inoculated seeds were incubated in a growth room where a cycle of 14/10 hrs light and dark regime was maintained at $60 \mu \mathrm{mol} / \mathrm{m}^{2} / \mathrm{s}$ provided by cool white fluorescent lamps (Philips Truelight 36w/86 6500 K B7, Philips India), and 60\% RH at $25 \pm$ $2^{\circ} \mathrm{C}$.

After two weeks of inoculation, some of the seeds were taken out and dispersed in one drop of water on a glass slide and observed under a light microscope. Per cent germination was calculated employing the following formula:

No. of seeds showing swelling of the embryo $\times 100$

Total no. of seeds

Once the spherules were formed, observations were recorded at one week interval to trace different stages of protocorm development. The whole operation was observed using a stereozoom microscope. Regular subculturing was done at an interval of 20 - 25 days.

For micropropagation, pseudobulb segments $(0.5-1 \mathrm{~cm}$ in size) of in vitro grown seedlings were cultured on different PGRs supplemented media. Multiple shoot buds (MSBs) that developed from pseudobulb segments were subcultured in different PGR supplemented media for induction of rapid elongation. When the shoot buds attained a height of $3-4 \mathrm{~cm}$ they were individually grown on the rooting media for induction of strong and stout root system. Well-rooted plantlets were taken out from culture vessels, their roots were washed thoroughly under running tap water to remove traces of agar and finally transferred to plastic pots containing a potting mixture of sterilized small brick-, charcoal pieces, and peat moss at a ratio of $1: 1: 0.5$ and kept in the greenhouse (at $25-30^{\circ} \mathrm{C}$ and RH $60-70 \%$ ).

The experiments were designed following Complete Randomize Design (CRD). Five replicates were taken per treatment for seed culture, whereas for micropropagation and rooting 10 replicates were taken. The effects of different media on germination of seeds, induction of shoot buds and roots in the in vitro experiments were tested applying Duncan's multiple range test $(p>0.5)$ in one 
way ANOVA. The statistical analyses were performed using the programme package Statistica ver. 7 (Statsoft, Tulsa, USA). The experiments were repeated thrice.

\section{Results and Discussion}

Germination of seeds occurred on both MS and PM media within three weeks from the date of inoculation. MS proved to be more efficient for germination of seeds $(95 \%)$ with a vigorous growth of protocorms compared to PM medium (72\%). Five distinct developmental stages of germinating embryos were observed during germination. Stage 1: No germination occurred, only viable embryos swelled up by absorbing water and nutrition (Fig. 1a), Stage 2: Swelling continued, cell number increased through repetitive anticlinal and periclinal cell divisions resulting in the formation of an irregularly shaped parenchymatous cell masses which came out by the rupturing of the seed coat (Fig. 1b), Stage 3: The parenchymatous cell mass contained dense chloroplasts, became compact with a few rhizoids at the posterior/basal part called spherule (Fig. 1c), Stage 4: The spherules enlarged in size and a growth appendicle appeared at the anterior portion delimiting the meristimatic zone for development of foliar organs; critically this stage is called protocorm stage and is supposed to be virtual germination of orchid seeds (Fig. 1d); Stage 5: The roots emerged from the basal part of the protocorms and gradually differentiated into young seedlings. Similar mode of differentiation of embryos was reported in Cypripedium acaule (Leroux et al. 1997), Platanthera clavellata (Zettler and Hofer 1998), Habenaria macroceratitis (Stewart and Kane 2006), Cymbidium aloifolium (Hossain et al. 2009), C. giganteum (Hossain et al. 2010) and Dendrobium aphyllum (Hossain et al. 2012). In fact, germination of orchid seeds followed a peculiar metamorphogenetic pathway during germination. The undifferentiated embryos gradually develop a round/ellipsoidal structure called protocorm which is an intermediate structure between the embryo and the plant (Batygina et al. 2003). When the protocorms were transferred to different PGRs supplemented MS, they multiplied profusely producing a huge number of secondary protocorms (Fig. 1e). After 2 - 3 subsequent subcultures, these secondary protocorms on the same media produced seedlings (Fig. 1f). For induction of secondary protocorms and subsequent seedling development MS fortified with $2.0 \mathrm{mg} / \mathrm{l} \mathrm{BAP}$ and $1.0 \mathrm{mg} / \mathrm{l}$ NAA proved most effective. Induction of secondary protocorms from primary protocorms in orchids is a common phenomenon greatly influenced by the specific plant growth regulators (Hossain et al. 2010). The secondary protocorms can be regenerated directly from the outer tissues of the protocorms (Huan et al. 2004), protocorm segments or thin cell layers (Teixeira da Silva et al. 2006, 2007). 
The pseudobulb segments of in vitro grown seedlings were cultured on different PGRs supplemented media. Thereafter, direct organogenesis occurred leading to the formation of multiple shoot buds (MSBs) on all the tested media (Table 1). The shoot buds regeneration was greatly influenced by the specific PGRs combinations. Shoot buds differentiation occurred directly from the dormant buds within four - five weeks of culture without an intervening callus phase. Differentiation continued until the end of the eighth week. Shoot buds first appeared as small, green protuberances that continued to grow and produce numerous axillary buds from the base. The highest number of MSBs $(7.75 \pm 0.17)$

Table 1. Development of multiple shoot buds* from pseudobulb segments of in vitro grown seedlings of D. aggregatum on different PGRs supplemented MS.

\begin{tabular}{lccc}
\hline $\begin{array}{l}\text { PGR combinations } \\
(\mathrm{mg} / \mathrm{l})\end{array}$ & $\begin{array}{c}\text { Time (days) } \\
\text { required of } \\
\text { sprouting of } \\
\text { MSBs }\end{array}$ & $\begin{array}{c}\text { Number of MSBs } \\
\text { sprouted /explant } \\
\text { (mean } \pm \text { S.E. })\end{array}$ & $\begin{array}{c}\text { Length (cm) of } \\
\text { individual shoot } \\
\text { buds after 30 days of } \\
\text { culture }\end{array}$ \\
\hline NAA+BAP & $40-45$ & $4.20 \pm 0.18^{\mathrm{f}}$ & $2.30 \pm 0.16 \mathrm{e}$ \\
$1.0+0.5$ & $30-35$ & $5.42 \pm 0.15^{\text {de }}$ & $3.35 \pm 0.08^{\mathrm{a}}$ \\
$1.0+1.0$ & $40-45$ & $6.53 \pm 0.22^{\mathrm{ab}}$ & $3.15 \pm 0.13^{\mathrm{bc}}$ \\
$1.5+1.0$ & $30-35$ & $5.60 \pm 0.26^{\text {cde }}$ & $3.25 \pm 0.15^{\mathrm{ab}}$ \\
$2.0+2.0$ & & & \\
BAP + picloram & $30-35$ & $7.75 \pm 0.17^{\mathrm{a}}$ & $2.17 \pm 0.13^{\mathrm{f}}$ \\
$1.0+0.5$ & $30-35$ & $5.80 \pm 0.18^{\mathrm{cd}}$ & $2.55 \pm 0.15^{\text {cde }}$ \\
$2.0+0.5$ & $35-40$ & $4.48 \pm 0.18^{\text {ef }}$ & $2.45 \pm 0.10^{\text {def }}$ \\
$2.0+1.0$ & $25-35$ & $5.70 \pm 0.26^{\text {cde }}$ & $3.25 \pm 0.12^{\text {ab }}$ \\
$2.0+1.5$ & & & \\
BAP + Kn & $30-35$ & $4.65 \pm 0.25^{\text {def }}$ & $3.10 \pm 0.12^{\text {bc }}$ \\
$1.0+0.5$ & $25-30$ & $5.05 \pm 0.15^{\text {de }}$ & $2.60 \pm 0.18^{\text {cde }}$ \\
$2.0+0.5$ & $25-30$ & $5.65 \pm 0.21^{\text {cde }}$ & $2.70 \pm 0.12^{\text {cd }}$ \\
$2.0+1.0$ & $25-30$ & $5.55 \pm 0.17^{\text {de }}$ & $2.50 \pm 0.10^{\text {de }}$ \\
$2.0+1.5$ & &
\end{tabular}

*Observations recorded from 10 cultured explants for each treatment.

sprouted when the explants were grown on $0.8 \%(\mathrm{w} / \mathrm{v})$ solidified agar MS fortified with $1.0 \mathrm{mg} / \mathrm{l} \mathrm{BAP}$ and $0.5 \mathrm{mg} / \mathrm{l}$ picloram (Fig. $1 \mathrm{~g}$ ). The requirement of exogenous auxins and/or cytokinins for regeneration of shoot buds and plantlet development has been reported for many orchid species (Arditti and Ernst 1993, Hossain et al. 2012). However, the combinations, concentrations, and the ratio between them are usually critically important (Hossain et al. 2010). The ratio of auxin to cytokinin for shoot bud formation varies from species to species (Teng et al. 1997). A striking synergistic effect of BAP for induction of shoot buds was reported in Geodorum densiflorum (Sheelavantmath et al. 2000, Bhadra and 
Hossain 2003), Rhynchostylis gigantea (Le et al. 1999), Vanda spathulata (Decruse et al. 2003), Cattleya (Melissa et al. 1994), Phalaenopsis and Doritaenopsis (Tokuhara and Mii 1993), Renanthera imschootiana and Vanda coerulea (Seeni and Latha 2000). The shoot buds underwent elongation on the same media and the highest rate of elongation was recorded on MS + $1.0 \mathrm{mg} / \mathrm{l} \mathrm{BAP}+1.0 \mathrm{mg} / \mathrm{l} \mathrm{NAA}$ (Table 1).

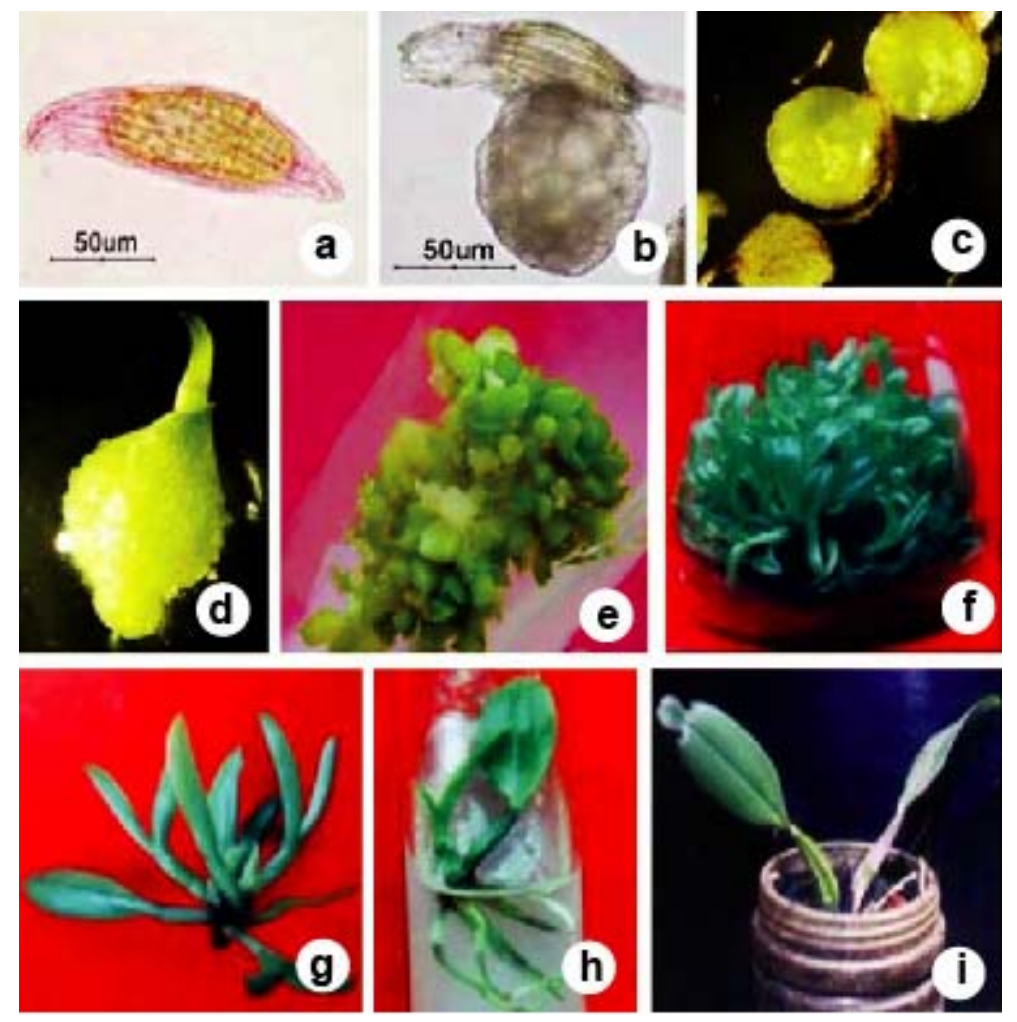

Fig.1. Seed germination and micropropagation of Dendrobium aggregatum: a. Seeds after one week of culture showing swelling of embryo, b. Parenchymatous cell mass coming out by rupturing testa, c. Spherules, d. A protocorm with leaf primordia, e. Profuse proliferation of protocorms producing secondary protocorms, f. Seedling development from protocorms, g. Multiple shoot bud development from pseudobulb segments, h. Induction of root system in shoot buds, and i. Establishment of in vitro grown seedlings in pot natural environment.

When the MSBs attained a height of $3-4 \mathrm{~cm}$, they were individually grown on different rooting media for induction of strong and stout root system. Half strength MS $+1.5 \%(\mathrm{w} / \mathrm{v})$ sucrose $+0.5 \mathrm{mg} / \mathrm{l}$ IAA proved to be more effective for induction of strong and stout root system (Table 2). Induction of roots is an inherent nature of plants which is controlled by endogenous level of hormones. Exogenous supply of root-inducing hormones like auxin enhances the process. Accordingly, the plant produces roots to uptake nutrient from nature. In nutrient deficit conditions the plant produces more roots to compensate nutrient i.e., 
deficiency, thereby inducing rooting. Thus the results of the present finding suggest that the combined effects of nutritional stress with IAA enhanced the development of a strong and stout root system in D. aggregatum (Fig. 1h). Similar results were also reported by Hoque et al. (1994), Bhadra et al. (2002, 2004), Hossain et al. $(2009,2010)$ in some epiphytic orchids.

The well-developed plantlets were transferred from culture room to the outside environment through successive phases of acclimation. Eighty per cent of the in vitro grown seedlings survived and continued to grow in pots in the greenhouse. They were finally established in Orchidarium of the Botanical Garden of Chittagong University (Fig. 1i).

Table 2. Development of root* system in individual multiple shoot buds of D. aggregatum when grown on different rooting media.

\begin{tabular}{ccc}
\hline $\begin{array}{c}\text { Rooting } \\
\text { medium }\end{array}$ & $\begin{array}{c}\text { Number of roots developed } \\
\text { per MSB } \\
\text { (mean } \pm \text { S.E.) }\end{array}$ & $\begin{array}{c}\text { Length (cm) of roots } \\
\text { after 30 days of } \\
\text { culture (mean } \pm \text { S.E.) }\end{array}$ \\
\hline $1 / 2 \mathrm{MS}$ & $2.25 \pm 0.25^{\mathrm{c}}$ & $2.45 \pm 0.22^{\mathrm{b}}$ \\
$1 / 2 \mathrm{MS}+0.5 \mathrm{mg} / \mathrm{I} \mathrm{IAA}$ & $3.50 \pm 0.16^{\mathrm{a}}$ & $3.65 \pm 0.18^{\mathrm{a}}$ \\
$1 / 2 \mathrm{MS}+1.0 \mathrm{mg} / \mathrm{lAA}$ & $3.00 \pm 0.16^{\mathrm{ab}}$ & $2.50 \pm 0.10^{\mathrm{b}}$ \\
\hline
\end{tabular}

*Observation recorded from 10 cultured shoot buds in each treatment.

The protocol developed in the present investigation for in vitro propagation of $D$. aggregatum offers a good opportunity to commercial orchid growers for large-scale propagation as well as for ex situ conservation of this orchid species. This protocol could be extended to other economically valuable, rare and endangered orchids for mass propagation and conservation.

\section{Acknowledgements}

The author is grateful to the Ministry of Education, the People's Republic of Bangladesh for providing financial support under grants for advanced research in Science.

\section{References}

Ahmed M (1991) A taxonomic study of the family Orchidaceae Juss. from Bangladesh. M. Phil. Thesis, Dept. of Botany, Chittagong University, Bangladesh.

Arditti J and Ernst R (1993) Micropropagation of orchids, Wiley \& Sons Inc., New York.

Batygina TB, Bragina EA and Vasilyeva VE (2003) The reproductive system and germination in orchids. Acta Biologica Cracoviensia Series Botanica 45: 21-34. 
Bhadra SK and Hossain MM (2003) In vitro germination and micropropagation of Geodorum densiflorum (Lam.) Schltr., an endangered orchid species. Plant Tissue Cult. 13: 165-171.

Bhadra SK, Barua AK, Bhattacharjee B and Hossain MM (2002) In vitro micropropagation of Dendrobium aphyllum (Roxb.) G. E. C. Fisher. Bangladesh J. Genet. Biotechnol. 3: 47-50.

Bhadra SK, Barua H and Hossain MM (2004) In vitro germination and rapid micropropagation of Bulbophyllum lilacinum Redley. Bangladesh J. Bot. 33: 103-107.

Decruse SW, Gangaprasad A, Seeni S and Menon VS (2003) Micropropagation and ecorestoration of Vanda spathulata, an exquisite orchid. Plant Cell Tissue \& Organ Cult. 72: 199-202.

Hoque MI, Roy AR, Sarker RH and Haque MM (1994) Micropropagation of Cymbidium bicolor through in vitro culture. Plant Tissue Cult. 4: 45-51.

Hossain MM (2008) Asymbiotic seed germination and in vitro seedling development of Epidendrum ibaguense Kunth. (Orchidaceae). Afr. J. Biotech. 7: 3614-3619.

Hossain MM (2009) Traditional therapeutic uses of some indigenous orchids of Bangladesh. Medicinal and Aromatic Plants Sci. Biotechnol. 3: 100-106.

Hossain MM, Sharma M and Pathak P (2009) Cost effective protocol for in vitro mass propagation of Cymbidium aloifolium (L.) Sw.- a medicinally important orchid. Eng. Life Sci. 9: 1-10.

Hossain MM, Sharma M and Pathak P (2012) In vitro propagation of Dendrobium aphyllum (Orchidaceae) - seed germination to flowering. J. Plant Biochem. Biotechnol. 22: 157167.

Hossain MM, Sharma M, Teixeira da Silva JA and Pathak P (2010) Seed germination and tissue culture of Cymbidium giganteum Wall. ex Lindl. Sci. Hortic. 123: 479-487.

Huan LVT, Takamura T and Tanaka M (2004) Callus formation and plant regeneration from callus through somatic embryo structures in Cymbidium orchid. Plant Sci. 166: 1443-1449.

Huda MK, Rahman MA and Wilcock CC (1999) A preliminary checklist of orchid taxa occurring in Bangladesh. Bangladesh J. Plant Taxon. 6: 69-65.

Knudson L (1922) Nonsymbiotic germination of orchid seeds. Bot. Gaz. 73:1-25

Le BV, Hang-Phuong NT, Anh-Hong LT and Thanh-Van KT (1999) High frequency shoot regeneration from Rhynchostylis gigantea (Orchidaceae) using thin cell layers. Plant Growth Regul. 28: 179-185.

Leroux G, Barabi D and Vieth J (1997) Morphogenesis of the protocorm of Cypripedium acaule (Orchidaceae). Plant Syst. Evol. 205: 53-72.

Melissa M, Sabapathi D and Smith RA (1994) Influence of benzylaminopurine and $\alpha$ naphthaleneacetic acid on multiplication and biomass production of Cattleya aurantiaca shoot explants. Lindleyana 9: 169-173.

Morel G (1964) Tissue culture- a new means of clonal propagation of orchids. Amer. Orchid Soc. Bull. 33: 437-478. 
Nagashima T (1999) A study of culture media for shoot apices and root in Habenaria radiata Sprengl. Conservation and propagation of endangered wild orchids of the world. In: Proceedings of the International Orchid Wave in Shimanami 99, pp. 29-33.

Seeni S and Latha PG (2000) In vitro multiplication and ecorehabilitation of the endangered blue Vanda. Plant Cell Tissue Organ Cult. 6: 1-8.

Sheelavantmath SS, Murthy HN, Pyati AN, Kumar HGA and Ravishankar BV (2000) In vitro propagation of the endangered orchid, Geodorum densiflorum (Lam.) Schltr. through rhizome section culture. Plant Cell Tissue \& Organ Cult. 60: 151-154.

Shefferson RP, Weiß M, Kull T and Taylor L (2005) High specificity generally characterizes mycorrhizal association in rare lady's slipper orchids, genus Cypripedium. Mol. Ecol. 14: 613-626.

Sinha P, Hakim ML and Alam MF (2009) In vitro mass clonal propagation of Spathoglottis plicata Blume. Plant Tissue Cult. Biotech. 19: 151-160.

Stenberg ML and Kane ME (1998) In vitro seed germination and greenhouse cultivation of Encyclia boothiana var. Erythrnioides, an endangered Florida orchid. Lyndleyana 13: 101-112.

Stewart SL and Kane ME (2006) Asymbiotic seed germination and in vitro seedling development of Habenaria macroceratitis (Orchidaceae), a rare Florida terrestrial orchid. Plant Cell Tissue Organ Cult. 86: 147-158.

Teixeira da Silva JA, Chan MT, Sanjaya, Chai ML and Tanaka M (2006) Priming abiotic factors for optimal hybrid Cymbidium (Orchidaceae) PLB and callus induction, plantlet formation, and their subsequent cytogenetic stability analysis. Sci. Hortic. 109: 368-378.

Teixeira da Silva JA, Giang DTT, Chan MT, Sanjaya, Norikane A, Chai ML, ChicoRuíz J, Penna S, Granstrőm T and Tanaka M (2007) The influence of different carbon sources, photohetero-, photoauto- and photomixotrophic conditions on protocorm-like body organogenesis and callus formation in thin cell layer culture of hybrid Cymbidium (Orchidaceae). Orchid Sci. Biotech. 1: 15-23.

Teng WL, Nicholson L and Teng MC (1997) Micropropagation of Spathoglottis plicata. Plant Cell Rep. 16: 831-835.

Tokuhara K and Mii M (1993) Micropropagation of Phalaenopsis and Doritaenopsis by culturing shoot tips of flower stalk buds. Plant Cell Rep. 13: 7-11.

Vijayakumar S, Rajalkshmi G and Kalimuthu K (2012) Propagation of Dendrobium aggregatum through the culture of immature seeds from green capsules. Lankesteriana 12: 131-135.

Zettler LW and Hofer CJ (1998) Propagation of the little club-spur orchid (Platanthera clavellata) by symbiotic seed germination and its ecological implications. Environ. Exp. Bot. 39: 189-195. 